\author{
Балша Н. СТИПЧЕВИЋ* \\ Филолошки факултет \\ Универзитета у Београду
}

\title{
КОНСТРУКЦИЈЕ С ГЕНИТИВНИМ СУБЈЕКТОМ: ПРЕЛИМИНАРНИ ПРЕГЛЕД
}

\begin{abstract}
У раду се даје преглед конструкција у којима се у српском језику јавља генитивни субјекат, како оних с одређеним синтаксичко-семантичким класама глагола (има воде, настало је проблема, нестало је струје, недостаје (ми) хране, треба ми ваздуха итд.), тако и оних где је генитивни субјекат корелат генитивног правог објекта (сипано је воде, јело се пасуља, једе ми се сланине, пријело ми се меса).
\end{abstract}

Кључне речи: генитивни субјекат, логички субјекат, субјекат, партитивни генитив, генитив, егзистенцијалне конструкције, егзистенција, посесивне конструкције, посесија, безличне конструкције, имперсоналне конструкције, безлични глаголи, имперсонални глаголи, рефлексивни пасив, партиципски пасив, пасив, синтакса, семантика, српски језик.

\section{Увод}

0. Да се субјекат може исказати генитивом, приметио је још Ђ. Даничић: илуструјући употребу и значења овог падежа, помиње случајеве „кад је оно подмет (субјект) што значи реч која стоји у другом падежу [= генитиву]”, и то уз глаголе „који значе бивање” и „уз глаголе у пасивној форми, али доста редко" (ДАничић 1958: 90-93). Све то илуструје и десетинама примера.

Иако ће већина граматичких приручника који ће излазити у наредни век и по наводити субјекат у генитиву као једну од типичних инстанци логичког субјекта, односно један од случајева употребе партитивног генитива (уп.

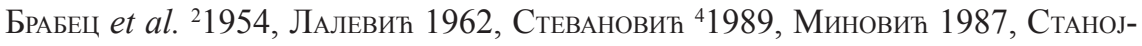
чић/Поповић ${ }^{13} 2011$, БАРић et al. ${ }^{2} 1997$, ПиПЕР et al. 2005 итд.), чини се да Даничићево запажање није изазвало довољно интересовања да се ова појава систематски истражи, а прилика за то није искоришћена ни у, иначе врло исцрпној, студији о српском генитиву (ФЕлЕшко 1995), где је оваквим конструкцијама посвећено непуне три странице.

\footnotetext{
*balsa@fil.bg.ac.rs
} 
Подстакнути утиском да је распрострањеност овог феномена нешто већа но што би се могло закључити на основу примера који се типично наводе у граматикама, овим радом покушаћемо да ту дескриптивну празнину умањимо тако што ћемо понудити илустрован преглед глаголских конструкција у којима се генитивни субјекат често или типично јавља, чиме би се створила дескриптивна база нужна за даљу анализу генитивног субјекта као синтаксичке појаве у српском језику. Инвентар глагола сачинили смо на основу шестотомног Речника Матице српске (скр. $P M C$ ), уз консултацију и Речника

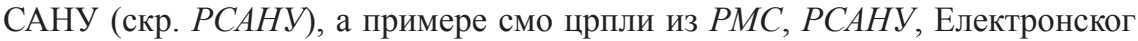
корпуса српског језика (скр. $E K C J$ ) и других електронских извора српског језичког материјала доступног на интернету (скр. ЕЛИ). У анализи се користимо терминолошко-појмовним апаратом из Поповић ${ }^{13} 2011$.

\section{Генитивни субјекат уз одређене синтаксичко-семантичке класе глагола}

\section{1. Еззистенцијалне конструкције}

Преглед ћемо почети егзистенцијалним конструкцијама, којима се генитивни субјекат у граматичким приручницима најпре илуструје. Глаголе смо поделили према томе да ли означавају „континуитет”, „почетак” или „престанак” егзистенције ${ }^{1}$, односно „неегзистенцију”. Можемо ипак претпоставити да је изван грађе остало још неких глагола (и типова конструкција) који имају примесу егзистенцијалног значења с генитивним субјектом. ${ }^{2}$

\section{1. Континуитет егзистенције}

1.1.1. Централни глаголи ове класе јесу имати и бити. Могу градити конструкције и с номинативним и с генитивним субјектом, при чему правила о томе када се користи - или може користити - који глагол, и с каквим субјектом, нису ни једноставна, нити, још увек, у потпуности схваћена. На основу обимне постојеће литературе (Грицкат 1961; Михаиловић 1972; Ивић 1981, 1982; Корин 1997; Кордић 2002; Ковачевић 2005; ЛАзић-Коњик 2005), чињенице које су релевантне за ову прилику могу се сумирати на следећи начин.

Опште је слагање да у презенту доминира глагол имати, а у претериталним временима (пре свега - перфекту) и футуру I - глагол бити, с тим што бити (укључујући и суплетивни презент јесам, перфективни презент будем

\footnotetext{
${ }^{1}$ Оваква подела начињена је и у раду Шпис 1987 , који садржи преглед седамдесетак глагола српског језика са егзистенцијалном семантичком компонентом, ексцерпираних из РМС и датих заједно с одређеним семантичким обележјима - нажалост, без примера. Мањи број тамо датих глагола гради конструкције с генитивним субјектом, а добар део њих егзистенцијално значење има само у фигуративној употреби.

${ }^{2}$ С. Кордић (2002: 145) примећује да велики број радова о егзистенцијалним конструкцијама не садржи никакву њихову дефиницију, а да се увидом у радове који је покушавају дати - види колико је такву дефиницију тешко формулисати.
} 
и варијанту за учесталост бивати), има заправо, ширу употребу. Прво, личне (= персоналне) копулативне конструкције са структуром суБЈЕкАТ + копулА + ПРИЛОШКИ ПРЕДИКАТИВ ((Te) ствари су на столу) По Правилу су Подложне Локационо-егзистенцијалној интерпретацији када им се ротирају прилошка и номинативна јединица (На столу су (неке) ствари), па се тада (ре)анализирају као лична егзистенцијална конструкција са структуром одРЕдБА МЕстА + ПРеДИКАТ + СУБЈЕКАТ. О којем се од два зНачења ради, може се разазнати на основу тога да ли номинативна јединица има одређену или неодређену референцијалну вредност те да ли има тематску или рематску информативну функцију, што све зависи од ширег контекста (в. нпр. Кордић 2002: 145-149 и тамо цитирану литературу). И друго - одавно је регистрована употреба егзистенцијалног презентског бити (и у личним и безличним конструкцијама) у неким врстама зависних реченица, пре свега временским и условним, као у Откад је света и века..., Да је среће..., Да је једно топло ћебе... (ФЕлЕшко 1995: 67, Корин 1997, као и КовАчевић 2005); такође, перфективно буде и фреквентативно бива може понекад функционисати и као примеренија алтернатива глаголу имати (КовАчевит 2005), као у Буде некад лепог воћа, Бива често лепог воћа и сл.

Што се тиче употребе номинатива (у личној) одн. генитива (у безличној конструкцији), као опште правило за глагол имати наводи се да се номинатив користи „кад је именица у једнини, бројива и у потврдној реченици”, а генитив - „кад је именица у множини” или „кад је небројива или кад стоји у негираној реченици" (Кордит 2002: 169). То би могло важити и за глагол бити, с тим да је продуктивност његових (личних) конструкција с номинативом нешто већа, захваљујући локационо-егзистенцијалним конструкцијама (их претходног става), и то, рекло би се, у свим временима и начинима.

У наставку дајемо табелу са свим варијантама потврдних егзистенцијалних конструкција, заједно с примерима. ${ }^{3}$

\footnotetext{
${ }^{3}$ Како би, колико је то могуће, конструкције биле еквивалентне у погледу нијансе егзистенцијалног значења и референцијалне вредности номинала, номинали су представљени незавршеном синтагмама песник који... (за бројиво) и вода која... (за небројиво). Каноничке конструкције дате су масним слогом и за њих не наводимо илустрације. Обичним слогом, без других ознака, дате су неканоничке али, по нашем осећају, још увек сасвим прихватљиве конструкције. Једним упитником $(?)$ су означене конструкције за које имамо потврду али их осећамо као маргиналне или теже прихватљиве ван разговорног језика, двама упитницима $\left({ }^{? ?}\right)$ - непотврђене такве конструкције, а звездицом (*) - неграматичне конструкције. Из табеле смо изоставили глаголске облике који су семантичко-прагматички блокирани (императив), морфолошки блокирани одн. непотврђени (једна варијанта плусквамперфекта и потенцијал II - уп. је било било, би било било; је било имало, би било имало) или пак одвећ ретки да бисмо за њих могли изнаћи потврде и за каноничке, а камоли неканоничке конструкције; из овог последњег разлога и глагол бивати дајемо само у презенту. Сем тамо где је наведено другачије, сви примери су из ЕЛИ. Морамо такође напоменути да смо из разматрања - и овде и у наредним тачкама - сасвим изоставили конструкције типа Много је воде. И у њима, истина, наилазимо на номинал у генитиву, али њега не сматрамо (генитивним) субјектом, већ зависним чланом партитивне синтагме; ту партитивну синтагму пак сматрамо граматичким субјектом који не може контролисати предикатску конгруенцију, као у Много људи је дошло (в. Поповић ${ }^{132} 2011$, такође и Стипчввић 2018). Ипак, допуштамо да се таквој анализи могу наћи мане те да овде можда имамо посла са нарочитим структурама, које завређују додатну пажњу.
} 


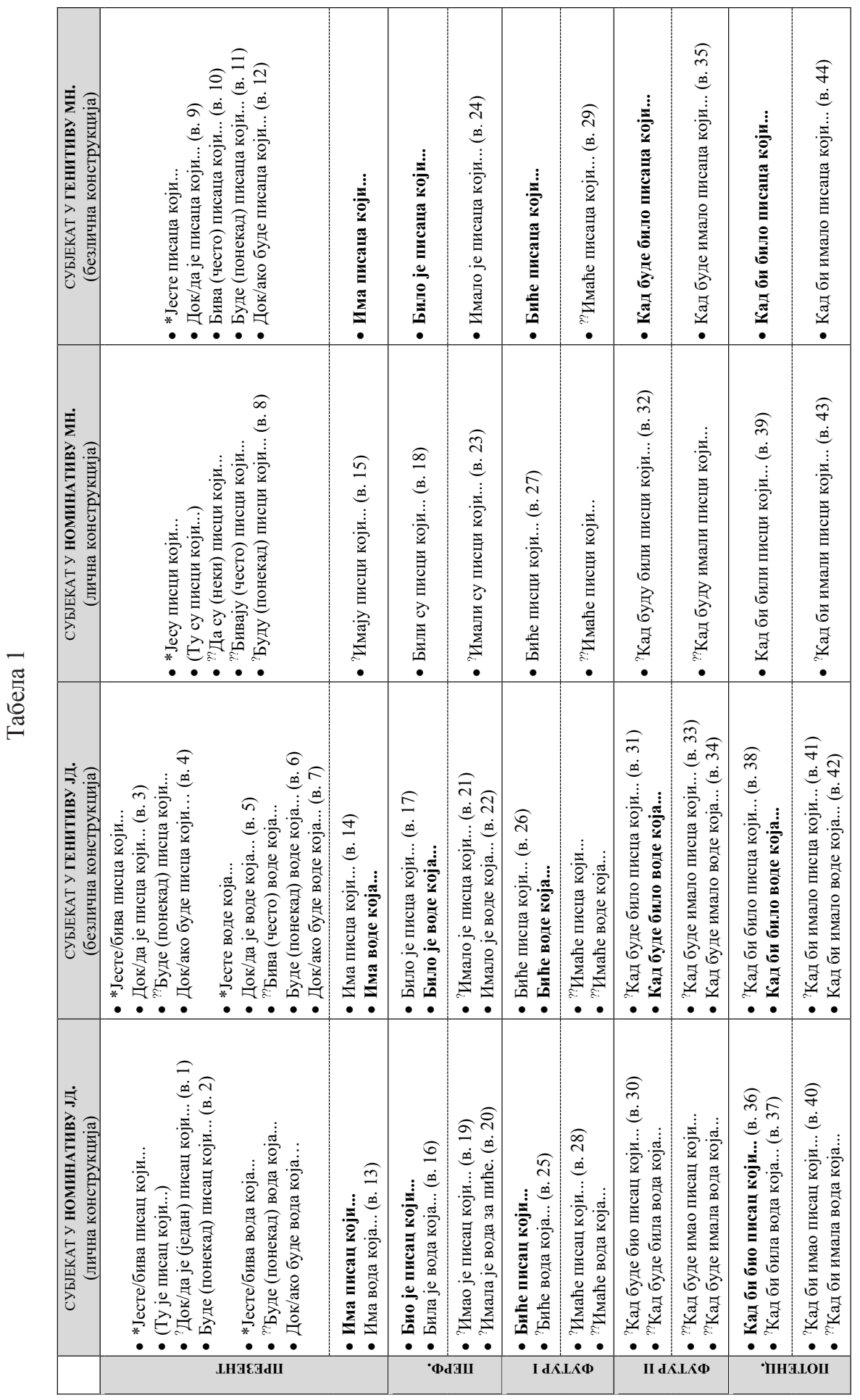




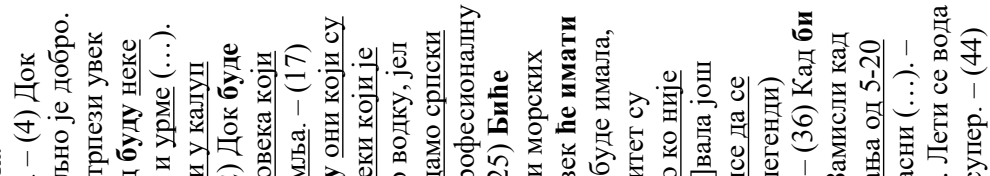
는

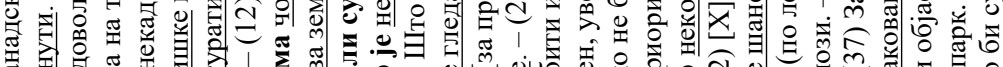

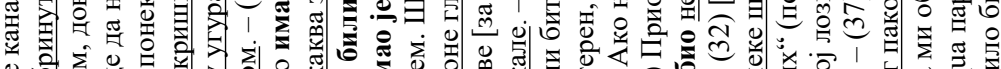

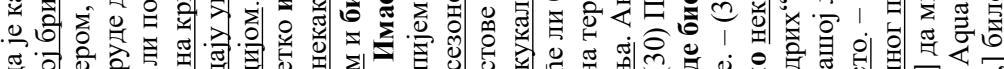

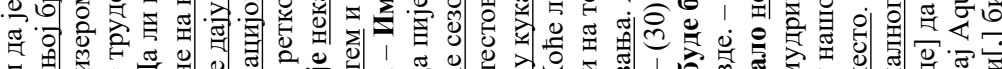

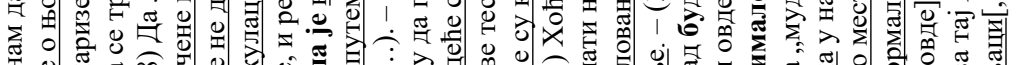

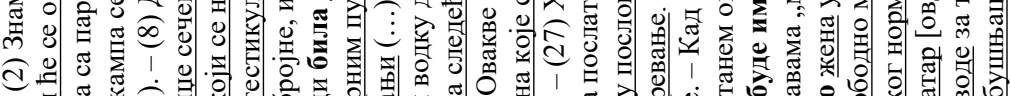

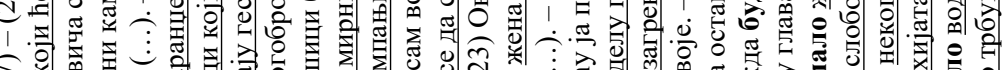

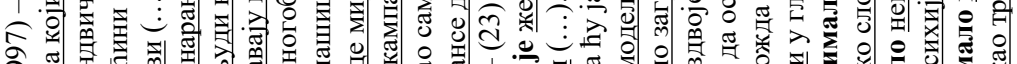

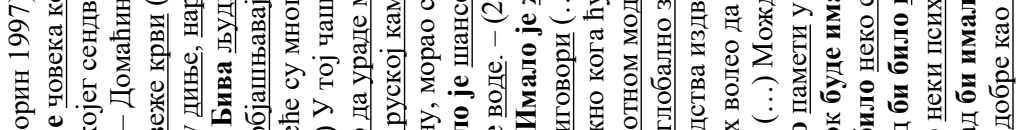
की. 일

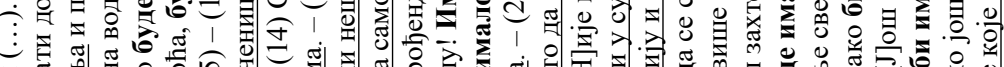

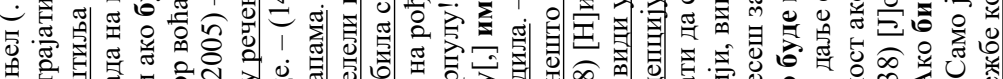

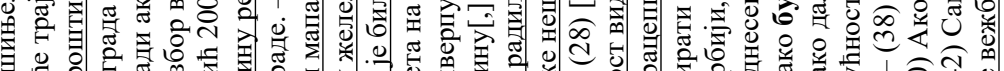

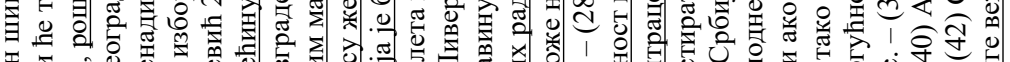

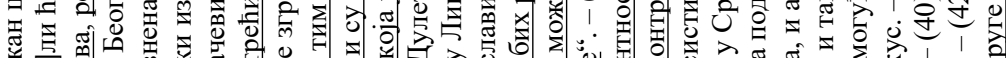

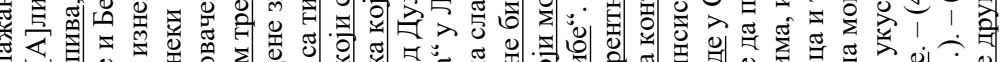

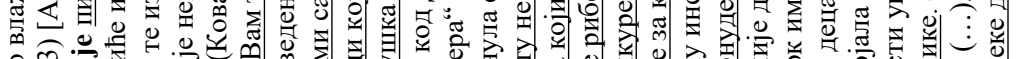
।

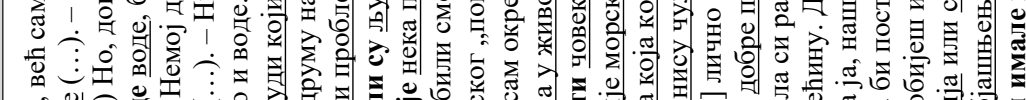

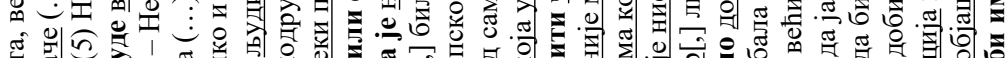

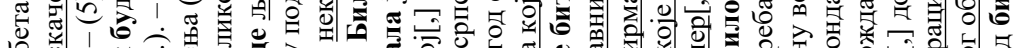

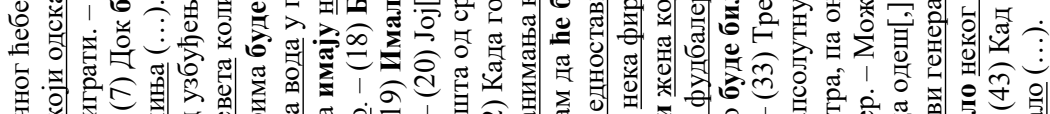

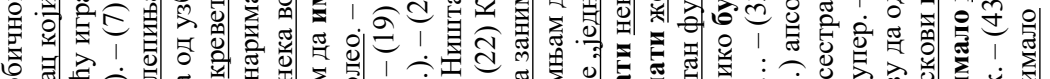

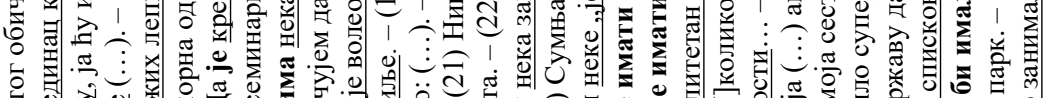

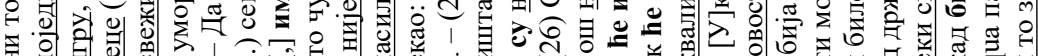

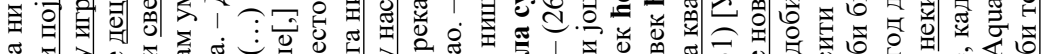

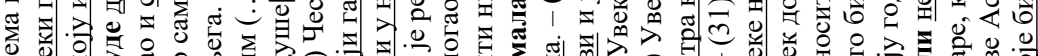

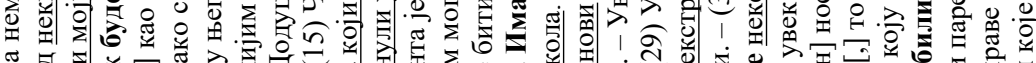

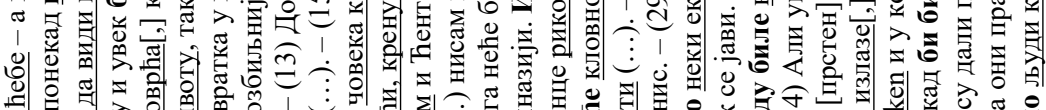

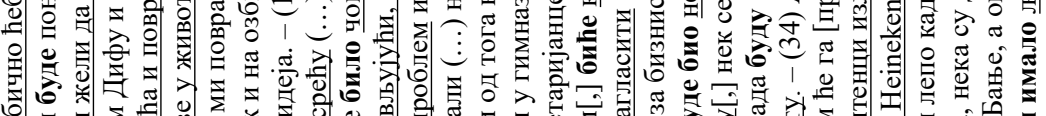

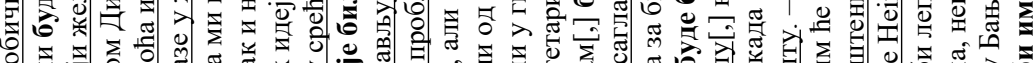

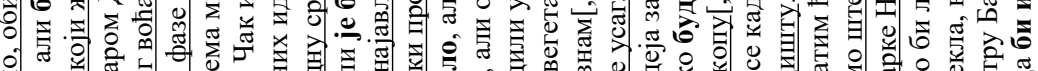

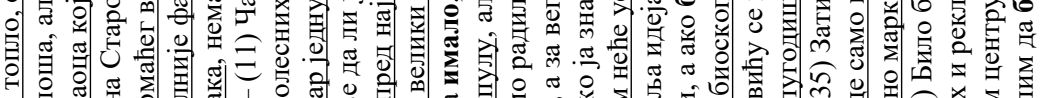

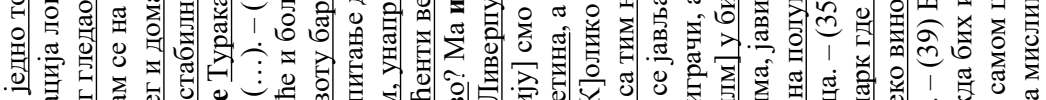

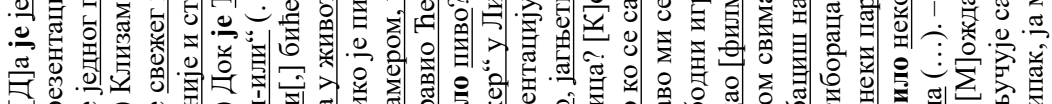

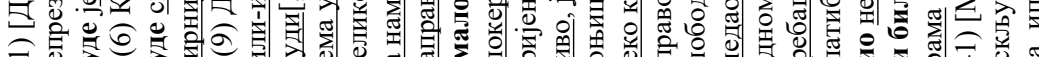

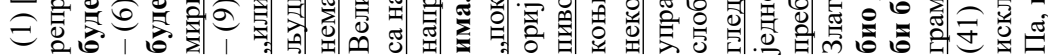


Примери из табеле 1 показују да се може врло лако наћи потврда за већину могућих комбинација датих лексемско-обличких параметара, иако, истина, многе потврде долазе из разговорног језика (одн. идиома блиског њему). Ако се узму у обзир и варијанте с негацијом (које у табели нисмо давали), конструкције с генитивом једнине из друге колоне постају, очекивано, много прихватљивије, чак и с неканоничким избором глагола (нпр. Huје имало писиа који није обожавао юен харизматичан глас [ЕЛИ]). Једини начин да се ова хаотична слика учини разумљивијом представљало би, по нашем мишљењу, пажљиво осмишљено експериментално истраживање које би обухватало и тестове прихватљивости и тестове спонтане продукције.

1.1.2. За глагол nостојати важи да има „чисто” лексичко егзистенцијално значење и да гради личне конструкције с номинативним субјектом, што се понекад наводи као једини могући начин његове употребе. Међутим, иако лична употреба убедљиво преовлађује, могу се наћи и безлични примери, с генитивним субјектом - и то не у малом броју. Поделили смо их на потврдне (а) и одричне (б):

(45a) Такође, данас постоји разних инжењера у најразличитијим областима - објашњава Ковачевић (...). - Увек постоји разлога за живот. - [П]остоји разлога за оптимизам (...). - У мом свету постоји места и љубави за свакога. - (...) док у галерији постоји места за још 340 гледалаца (...). - [У] њему је постојало нечега „донкихотовског” (...). - Увек сам имао неки специфичан однос са другарицама и увек је ту постојало неког мувања и неких двосмислености. - Обожавао сам Будву (...), када је била напредно туристичко место у коме је постојало неког шарма. - Такав прави приступ објашњењу топонима само потврђује ону стару, озбиљну теорију да су Словени на Балкану живели откад постоји света. - Знала сам да је ту постојало нечега, али његово признање је нешто сасвим неочекивано. - Ако и може нешто бити за утеху, добро је што постојите Ви, само кад би постојало таквих и у влади наше лепе Србије. - Када би постојало таквог притиска, то би упућивало да ми нијесмо држава[,] него колонија. - А зашто му је исплаћен тај новац, ако постоји доказа да га није зарадио? - Ако постоји неких несугласица, дође до сукоба. (ЕЛИ)

(45б) Да је могао град да живи без села, села не би постојало. - Ово је и даље био свет ниских енергија - није постојало слободног кисеоника[,] који је допуштао животињама на Земљи да живе (...). - [Нисмо] имали пробоја, није постојало снаге да се „разбије” противник. (EKCJ) - Међутим[,] полиција не позива на раздвајање публике на дербију јер није постојало доказа о хулиганизму присталица ова два тима. - И слеп човек види да није постојало намере да удари голмана. - Милијардама година није постојало ничега. - У таквим околностима, до сада није постојало неког значајнијег подстицаја за укључивање цивилног сектора у процесе мониторинга власти (...). - [T]о је територија за коју тад није постојало неког великог интересовања. -Наравно[,] улица је асфалтирана као прилаз кућама пре двадесетак година[,] када није ни постојало никаквог плана. - Није постојало никаквог разлога да се помињу националне мањине у званичном имену те државе. - Колико знамо[,] у њиховом односу није постојало никаквих трзавица (...). - После демонстрације мотор је отворен и није 
постојало ни најмањег знака хабања, оштећења, прегревања. - Дакле, Османлијско царство нити је било легални суверен територије Србије (...) јер није постојало никаквог споразума, никаквог уговора којим би то прави било њима признато. - Није постојало никаквог малтретирања, понижавања и шта ти ја знам чега све бива у сличним везама. - Према речима лекара, Петра је јако добро реаговала на терапије и није постојало никаквих сметњи. - Међутим, уколико то не буде могуће у догледно вријеме, уколико једноставно не буде постојало таквог позитивног рефлекса на српској страни (...). - Отуда су Хрвати до дан данас тако екстремно клерикално настројени, јер кад не би постојало тог клерикализма и папољубља, јасно је да (...). - Када не би постојало тог минумума[,] једноставно би људи гледали да се снађу на друге начине (...). - Да није било „бувљака”, сигурно данас не би постојало ни Србије, као ни других држава у региону. (ЕЛИ)

Пошто не можемо означити ове примере као неграматичне, па ни нарочито необичне, рекло би се да многи говорници постојати употребљавају на потпуно исти начин као глаголе имати одн. бити, с тим што се види да у огромној већини генитивни номинал карактерише референцијална неодређеност. Утисак је и да је безлична употреба с генитивним субјектом још мање необична под негацијом, поготово с појачивачима одричности као што је $н и$ какав, или пак у модалном контексту (последња четири примера из (45a) и (456)).

1.1.3. И глагол жсивети може се убројити у егзистенцијалне (ЛАзић-Коњик 2009: 365). Он показује двоструки конструкциони потенцијал који одговара оном који смо поменули у вези с копулативним и егзистенцијалним бити: с једне стране, живети припада глаголима који захтевају прилошку допуну за место и гради конструкције с граматичким, (типично) тематским субјектом и рематским месним адвербијалом (Ти људи живе $\underline{m y}$ / месту / ...), а с друге стране, с рематизованим и (типично) референцијално неодређеним субјектом и тематизованим месним адвербијалом - гради егзистенцијалну конструкцију (Ту живе разни људи). ${ }^{4}$ Премда би се с овим глаголом очекивале искључиво такве, личне конструкције, забележили смо и један пример с генитивним субјектом:

(46) Иначе[,] тадашњи Персијанци нису спадали у Арапску групу народа пре свега зато што је то била огромна држава, у којој је живело свакаквих народа.

\footnotetext{
${ }^{4}$ То важи и за (прото)типични овакав глагол - налазити се. Њега не помињемо јер нисмо забележили безличну употребу с генитивним субјектом (? $T$ у се налазило разних ствари), мада нам се не чини немогућа. Такође, за глагол расти је већ у литератури истицано да подразумева „егзистенцијално детерминисану” локацију (Ивић 1982), па бисмо, слично ономе што важи за глагол живети, егзистенцијалном могли сматрати реченицу У тој иуми расту неке чудне печур$\kappa е$, чије имперсоналне варијанте с генитивом - У тој шуми расте неких чудних печурака / У тој шуми никад није расло печурака - не делују неприхватљиво; но, ни за их немамо потврда.
} 
1.1.4. Данас архаично, егзистенцијално значење глагола тећи дефинисано је у РMC као „постојати, егзистирати” и илустровано је једном безличном генитивном конструкцијом; другу можемо наћи код Ђ. Даничића:

(47) Дивни обичај ... предаваће се ревносно с колена на колено докле тече сунца и месеца. (PMC) - Докле сунца, докле винца тече. (Даничић 1958: 91)

Мање архаична је употреба егзистенцијалног трајати:

(48) Снимај пену дотле док је траје..$^{5}$ - Ти ћеш живјет' док Турчина траје. - Док трајало неба и Србинства. (Даничић 1958: 91) - [Реферат] ће (...) остати стегнут у девичанској „фасцикли”, невиђен и нечитан, док траје света и у њему рукописа и хартија. - [Д]ок је трајало и последње паре у државној

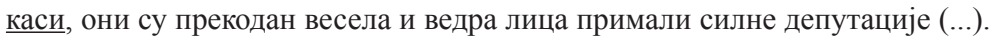
$(E K C J)$ - А када је реч о борбеној линији, они би били на њој док траје хране и џебане, практично до смрти. - Има програма за сваког и док траје вина, рибе и пива[,] манифестација ће трајати (...). (ЕЛИ)

Глагол тећи би се теже могао егзистенцијално употребити у личној конструкцији, а оба глагола се, како видимо, срећу искључиво у временским клаузама с везником док(ле) које значе меру времена, и то тако што се престанак егзистенције појма у вишој клаузи везује за престанак егзистенције појма у временској. То је вероватно и разлог што савремени говорник, како нам се чини, овакве клаузе интерпретира у „партитивном” кључу: појам у генитиву концептуализује се као материја која се временом троши и нестаје.

1.1.5. Глагол остати има врло развијену полисемантичку структуру - у РСАНУ се она представља кроз чак четрдесет пет (под)значења. Једну од својих фреквентних употреба глагол има онда када је потребно неки појам локализовати: тада захтева прилошку допуну за место (мировања), слично глаголу налазити се (негде) одн. наћи се (негде). Но, за разлику од глагола налазити се / наћи се, глагол остати индукује, као што примећује А. Јовановић (2018), једну јасну пресупозицију: реченица Демонстранти су остали на тргу подразумева да је постојало очекивање, потреба, жеља и сл. - да трг напусте. Стога се његово значење може грубо парафразирати као „[ипак] наставити бити (негде)”. А као глагол који служи локализовању неког појма, слично већ поменутом глаголу живети, лако гради и конструкције које имају егзистенцијалну перспективу, било с номинативним (На тргу су остали неки људи), било с генитивним субјектом, с којим друго значење осим егзистенцијалног, рекло би се, није ни могуће:

(49) Погодили су улазна врата, а кроз рупу коју су направили, успели су [терористи] да уђу у кампус. Постоје излази у случају опасности кроз које смо успели да изађемо. Али, тамо је остало људи. (ЕЛИ)

\footnotetext{
${ }^{5}$ „Скидај пену дотле док је има.” - пример је из винарског приручника М. Болића: пена се ствара приликом прављења вина и потребно ју је уклањати све док не престане да надолази.
} 
У горенаведеном примеру подразумева се да су неки студенти, пред очигледном опасношћу, успели да напусте кампус, док неодређени број других није, иако су хтели. Дакле, егзистенцијално остати конкурише егзистенцијалном бити и имати управо тим прагматичким моментима. И у наредним примерима употреба баш глагола остати (а не бити или имати) носи извесне конвенционалне претпоставке, које варирају зависно од тога какав ентитет је посреди и какво му је место и улога у свакодневном људском искуству: неке материје су непожељне увек, а друге ван своје уобичајене употребе; храна, пиће, новац, гориво и различите друге материје служе да се троше, а као нешто што је намењено трошењу концептуализују се и (слободан) простор, време, љубав, аргументи итд. УП.:

(50) [И]спрала сам их [печурке] да будем сигурна да није остало песка и нечистоће (...). - Научници су потврдили да у [палом] сателиту није остало неког опасног материјала (...). - Сви око мене су завршили с јелом, али је опет остало хране. (ЕЛИ). - Ако остане пара на рачуну, кажу привредници, онда се измирују порези на добит (...). - Пракса је да у авиону увек остане горива за најмање додатних пола сата лета (...). - За то [= упис] имају шансу до 31. августа у школама где је остало места - напоменуо је Лазаревић. $(E K C J)$ - Можемо да се играмо напољу тек кад завршимо домаћи, ако остане времена. - Није у њима остало љубави ни за партнеpa, а камоли за децу. - [Д]иректор производње [наглашава] да је из овог периода остало аргумената који ће послужити као основ за ново рађање индустријске производње (...). (ЕЛИ)

Видски парњак остајати користи се на исти начин:

(51) [Брисач] није равномерно распоређивао притисак на метлицу[,] па је на средини остајало воде. - [Препарат је] невероватно питак, у потпуности се растворио (...), не остаје никаквог праха на дну чаше (...). - Ружно је да у буџету општине остаје новца за спорт, а да деца из Прокупља (...). (ЕЛИ) - [Д]о почетка следеће сезоне остаје времена да се сваки објекат постави на своје место (...). (EKCJ)

1.1.6. Глаголи преостати и преостајати синонимни су својим непрефиксираним парњацима, али не увек: рекло би се да имају нешто суженију употребу, односно да се појам у генитиву по правилу концептуализује као нешто што је намењено трошењу, док су друге могућности искључене (уп. $V$ благајни је преостало новиа, али ?? На печуркама је преостало прљавитине). Наводимо само неколико примера из грађе:

(52) Уколико после намирења поверилаца из првог исплатног реда у деобном маси преостане средстава, намирују се повериоци другог исплатног реда $(\ldots) .(E K C J)-[И]$ маш право да упишеш онај смер са листе на ком је преостало места. - [3]адовољан сам, преостаје новца за пристојну штедњу. - Резултат је био нагло повећање производње житарица, којих је преостајало и за извоз (...). (ЕЛИ)

1.1.7. У релативно маргиналну и понешто архаичну, али занимљиву синтаксичко-семантичку класу улазе егзистенцијални глаголи достати/до- 
стајати, дотећи/дотицати, достићи/(достизати) и дотрајати. Њихово значење могло би се парафразирати са „бити довољно (нечега)”, где генитивни субјекат обично означава материју која се временом троши (за неку сврху). Примера немамо много:

(53) Константин је ... узео из грчке азбуке сва писмена, а што их није достало, узео је ... из глаголице. (РСАНУ) - Има читавих живота из којих, кад би изабрао све узбудљиве тренутке, лепе и ружне, - не би достајало материјала за целовечерњу драму. - Али душо, ако би пут био исувише трновит да не би достајало Твоје снаге да га крчиш, потражи (...). (ЕЛИ)

(54) У сеоској цркви не дотјече мјеста за толики ... народ. - Свашта ће дотећи, а памети никада [неће дотећи]. (РСАНУ) - У двору се госте, та и керовима [= за керове] је дотекло батака (...). - [Н]ацртало би се двориште, и у њему патке и гуске (...), али за свињу не би дотекло боје и папира. (ЕЛИ)

(55) Можда је имо̂ кнап 2 милиона (...) и на крају није достигло пара за контејнере. (ЕЛИ)

(56) Неће сијена дотрајати до Божића. (РСАНУ)

Ови глаголи могу градити и личне конструкције с номинативним субјектом, али тада се егзистенцијална семантика губи и глаголи попримају значење копулативне конструкције „бити довољан” (уп. Јер пензија юезине мајке једва достаје за кирију... [EKCJ]).

1.1.8. Глаголима из претходне тачке блиски су глаголи претећи и претицати, који приближно значе „бити вишка (нечега)”, а у генитиву је опет типично материја која се користи за неку сврху. Уп.:

(57) Само у 10 случајева повериоци су намирили сва своја потраживања, а тек у незнатном броју претекло је новца[,] који је уплаћен у буџет (...). - (...) на месту где је Христос (...) нахранио хиљаде људи, а да је хране још и претекло. $(E K C J)$ - Али, не ове[,] већ неке наредне године када претекне пара у буџету. - Сликар се четкице лати кад има инспирацију, али и кад претекне времена за рад у миру и тишини (...). - Велика је штета, што вероватно неће претећи пшенице и за извоз (...). - [У емисији су] додавали, ако је претицало места и минута, понеки необавезан (...) прилог. - Уосталом, никада на селу није претицало пара за кућне помоћнице. (ЕЛИ)

\section{2. Почетак егзистенције}

1.2.1. Међу глаголима који значе „почетак егзистенције”, код пет смо, поред личне номинативне, регистровали могућност грађења безличне генитивне конструкције - искрснути, настати, настајати, појавити се, појављивати се:

(58) [Али] ми искрсло неких проблема, па покушавам још данас то да решим (...). (ЕЛИ)

(59) Јасмина је лепо почела, али је у рефрену настало проблема! - [T]у би могло да настане неких проблема[,] а то је везано за ожичење и филтрирање напона (...). - Веома је важно да не настане никаквих проблема у вези безбедности мора. - Леова најбоља другарица је Ноа (доберман) и ево већ 
се месецима интензивно друже а да никада ни за тренутак није настало ни најмање иритације међу њима. - Па да није Бога[,] не би настало ни Писма, па како онда да Бог није заслужан за канон? (ЕЛИ)

(60) $[$ К]ад би сви возили полако и пажљиво[,] не би настајало проблема (...). (ЕЛИ)

(61) [M]еђутим, ту се појавило људи из 12 земаља[,] за које нисмо ни очекивали да могу доћи. - Ипак, недавно се појавило неких опипљивих доказа о присуству (...) напредне цивилизације, која није створена од стране Кинеза. - Ако је и неко из МУП-а умешан у читав тај догађај, а бојим се да тога има јер видимо да се појавило свакаквих информација и индиција (...). - Преко ноћи се појавило разноразних дуња и кајсија [= ракија, одн. врста ракије]. Објавите како се оне праве и колико има произвођача који праве те ракије од воћа (...). (ЕЛИ)

(62) Видим да се у старим темама појављивало људи који су били потпуно нови овоме, али и оних са доста разноврсних искустава. (ЕЛИ)

Генитив једнине налазимо у два примера, с глаголом настати, оба под (појачаном) негацијом (није настало ни најмағе иритације, не би настало ни писма), а у осталим примерима генитивни субјекат је у множини, односно само тако се може разумети (уп. *али је у рефрену настало неког проблема).

1.2.2. Егзистенцијалну семантику можемо препознати и у конструкцијама које граде глаголи искупити се, наваьати се, навејати, накотити се, намножити се, нагомила(ва)ти се ${ }^{6}$, накупити се / накупљати се, нападати, с(а)купити се / с(а)купљати се, слити се, сјатити се. Примери:

(63) Чекали смо пар сати и искупило се народа за пун камион. - [И]скупило се раје па свако своју причу тера. (ЕЛИ)

(64) [Т]ренутно још немам довољно времена да се упустим у то јер ми се наваљало неких ситних послова док сам се борио (...). (ЕЛИ)

(65) Због тога се тешко и загрејемо, а напољу зна да навеје снега јер су ово обронци планине - наставља причу бака испред трошног кућерка. (ЕЛИ)

(66) Накотило се некакве дечурлије, малих голуждраваца, који се деру из свега гласа - Наши гину, а крштеног гада се накотило, краја му нема! - Ух, накотило се гамади! (РСАНУ) - Домаћих издајника се накотило ко зечева, а и окупатора је све више. - А те се жгадије накотило, ти боже знај. $(E K C J)$ - Код нас се накотило паса, будала никад није ни фалило (...). - (...) да можда и њима сутрадан на врата закуца неки маскирани грађевинац јер је чуо да се баш ту накотило змија, пацова и наркомана, па ето, да мало рашчисти. - Накотило се патријархалних хипстера и дечурлије која језиво преписује дубокоумне мисли (...). - И тако се накотило тих колумниста разних фела. - На ФДУ се накотило тих лажних доктора и докторки (...). $($ ЕЛИ)

(67) Како је суд (...) зарачунавао и вишегодишње камате, накупило се тога (...). - Накупило се свуда сецикеса и разбојника, а овде још и цео гарнизон (...). - За двадесет и четири часа накупило би му се воде таман за једну малу кафену кашичицу. - [J]а сам писала песме и сада се коначно накупило

\footnotetext{
${ }^{6}$ За несвршени парњак нагомилавати се немамо примере, али нам конструкције попут Сваки пут би се ту нагомилавало неког смећа делују прихватљиво.
} 
материјала да урадим албум. - У Дејану се накупило гнева (...). - Тамо се накупило греха као плеве. (EKCJ) - Види да се није негде накупило неке прљавштине (...). - Ми смо Бећарац [= плажу] чистили и прошле године, али ето, опет се накупило разних отпадака и ђубрета (...). - [O]пет се у њој [= коси] накупило неких непријатних мириса (од дувана или кувања) (...). - [C]тискам цео прст како би се на јагодици накупило крви (...). (ЕЛИ)

(68) Намножило се разноразних колекција од необичних „стварчица” које је овај љубопитљиви човек доносио из (...). - (...) истиче Табаковићева, додајући да се протеклих година намножило агенција „за све и свашта”. - [К]раду сви којима то образ дозвољава. Таквих се намножило па је отупела и морална оштрица јавности. - Кад би чуо да се у некој вароши намножило самсара, Књаз Милош је настојао да их „разреди” на подношљив број (...). (EKCJ) - Јуда је назван благајник издаје. Тих благајника се намножило. - Намножило се политичких и интелектуалних бесловесника који нас утерују у „демократију” (...). - Како коментаришете тренутно политичку ситуацију у Србији, да ли се намножило разних Шојића? (ЕЛИ)

(69) Постало је мало нелогично. Нагомилало се зелених зона. - Јер у Србији се протеклих деценија нагомилало сувишних „папира” којима је одавно истекао рок трајања (...). - А таквих поступака се у међувремену нагомилало: (...). (EKCJ) [М]ожда ти се нагомилало неког ђубрета [на хард-диску]. - [И] баш кад ми се нагомила веша[,] онда је замолим (...). - [К]ућиште је добијало сваких два-три дана усисавање предње странице пошто се нагомила прашине. - Нагомилало се обећања, расте незадовољство, пуно тога је обећано. - Нагомилало се неког посла, обавеза, решавам то у ходу. - Ситница по ситница и ни не приметите да се нагомилало и функционалних и нефункционалних ствари. - [Људи] не знају увек да ли чине добро или лоше, све док се не нагомила тог лошег. (ЕЛИ)

(70) Ала је нападало снега! (EKCJ). - Нападало снега у марту малте не као за целу зиму. - Устали, па пошто је нападало снега, (...) кренули смо низбрдо. - [К]ад ми буде нападало снега у улици[,] знам кога да позовем, није Пожаревац далеко. - Послали нам другари пре сат времена стање на сомборском путу (...). Нападало леда, а тренутно пада киша у Суботици. - Само џаба ми и то кад је задњих 3-4 дана нападало кише за читаву годину. - [Ш]то се фарбања тиче, пробао сам на тераси (...), али је опет нападало прашине и труња па сам морао да поновим (...). - [M]и имамо у дворишту крушку стару сто година (...), кад напада лишћа[,] не можеш да прођеш (...). (ЕЛИ)

(71) Народа се скупило као ретко кад (...). (EKCJ). - Мени се скупило сала око струка (...). - На ту се примедбу, наравно, скупило разног света да ми нељубазно објасни како мастим књиге и којешта (...). - [У] навијачким групама се скупило свакаквог талога (...). - Ту се скупило свакаквог живља (...). - Надам се да се играчима скупило беса због овако баксузног почетка (...). - Претпостављам да се скупило прашине испод кревета (...). - [3]вучи као да му се скупило шлајма у грлу. - Ја подржавам Александра Вучића, али у локалу се у тој странци сакупило разног света. - PНА је затворио дотичну тему пре који месец јер се стварно почело скупљати разних срања, али ево, прошло је неко време (...). (ЕЛИ) 
(72) Слило се те среде, поподне на брдашце повише Аутокоманде - разног народа. - Не заборави да се последњих двадесет година у Београд слило људи са свих страна (...). (ЕЛИ)

(73) [Т]оком рата ту се сјатило којекаквих усташких екстремиста из целог света (...). - Чекали смо (...) у фризерају, јер се сјатило тих господских, добро очуваних бакутанера. (ЕЛИ)

Свим горе представљеним конструкцијама заједничко је то да се њима потенцира настанак неодређеног мноштва бројивих ентитета или неодређене количине конкретне или апстрактне материје, и то на одређеном месту, које може бити експлицирано или пак подразумевано из контекста. Глаголи се разликују по томе какве генитивне референте допуштају, па се тако $н а$ купити се користи с бројивим и небројивим номиналима било које врсте, намножсти се - с бројивим и збирним, накотити се - с бројивим, збирним, и то аниматним (животиње, а у чешћој, пејоративној употреби, особе), навејати - само с именицом снег (уз евентуалну, у нашој грађи незабележену, ширу фигуративну употребу с другим именицама) итд. У анализи оваквих конструкција могли бисмо постулирати имплицитни квантификатор („много”, „доста"). У неким случајевима, уместо експлицитне квантификације пуном партитивном синтагмом, говорник то чини индиректно (уп. 3aдюux 3-4 дана нападало је кише за читаву годину, Народа се скупило као ретко кад, Искупило се народа за пун камион и сл.). Конструкције с глаголима слити се и сјатити се овде уврштавамо само условно, будући да за њих имамо мали број примера, и то само с особним генитивним номиналима.

\section{3. Престанак егзистенције}

1.3.1. У глаголе који значе „престанак егзистенције” а граде (личне номинативне и) безличне генитивне конструкције спадају глаголи неста(ja)mu и понеста(ja)mu. Примере за глагол нестати разврстали смо према томе да ли садрже (а) уникатне ентитете одн. властита имена, (б) бројиве ентитете у једнини, (в) небројиве ентитете и (г) бројиве ентитете у множини:

(74a) У један пут шкљоцну брава ... Моје мајке неста са прозора. (РСАНУ) - Још онога дана кад је нестало Ханса Касторпа, он је пришао Јоахиму (...). - Али сутрадан је нестало без гласа и јава и Лебјаткина и његове сестре (...). - Швејк оде да потражи госпођу Милер (...), али ње је нестало без трага. -Тај пламен (...) у коме је требало да нестане малене и храбре Србије, претворио се у Феникса Слободе (...). (EKCJ) - Кад је нестало Тита[,] националне струје су почеле поново да јачају (...). (ЕЛИ)

(74б) Нестат ће кризе ко јутарње маглице. (РСАНУ) - Загоретина са дна лонца (...) уклања се ако се (...) метне једна шака соли и пусти да вода кључа извесно време. Загоретине ће брзо нестати. - Али, више нећу да чујем за појаву да сте лек наручили за три месеца, а да га нестане већ за седам дана. - Од свих њих је остао само белоглави суп, а и њега би нестало да (...) нису отворена хранилишта. (EKCJ) - Са њим је нестало и последњег пушкара у Гори. Једини остаци тих заната су стари алати, који се још могу 
наћи. - [J]ер тек кад нестане и последњег дрвета на овој планети, људи ће схватити да се паре не могу јести (...). (ЕЛИ)

(74в) Службеница на шалтеру (...) одговорила је да је инсулина нестало. На питање кад је нестао када га скоро није било, одговорила је (...). - Озлојећености је нестало из њеног гласа (...). - Треме је нестало. - Ноћ слепог човека не мења се када нестане светлости (...). - Нестане струје и воде, па морам да имам и резерве у цистерни (...). - Уверење да ће временом нестати сиве економије са улица Милосављевић је поткрепио чињеницом (...). - [Н]аши народи теже (...), да нестане рата и насиља, владавине једног народа над другим (...). - Таман и кад би нестало српског народа, опет би Ватикан, Загреб и такви као што си ти трубили (...). - Чим би газда неким послом отишао из радње, (...) [y] кревету је, док је радио тихо свирао, нестајало њене намршености и строгости (...) - Павловићевог оптимизма није нестало ни после седнице Одбора за приватизацију (...). - Благи боже, куд је нестало овог одмора! Протекао, пролетео, прошао (...). - У последњој борби, када је већ нестало и муниције (...). - (...) па су га [банкомат који је погрешно исплаћивао двоструко веће износе] клијенти празнили све док није нестало новца. (ЕКCJ)

(74г) Највише је по чаршији брујало, како је из суда нестало некаквих важних акта. - И кад на овом свету нестане брегова и људи, мени се чини, још ће трајати два црногорска колоса (...). - Током времена нестало је великих шума, па и у нашем крају. - Када би животиња нестало, човек би умро од велике усамљености духа. - [О]ни који долазе треба (...) да се навикну на дуже рестрикције струје када нестане залиха дизела за агрегате (...). - И када би се Роки [= споменик] нашао у центру Житишта, не би нестало поплава, сточних болести, пијанки и туча. - (...) У реализму Макјајолија није нестало трагова сентименталности сликарства позног осамнаестог века ни лиризма романтичара (...). (EKCJ)

(75) $[\mathrm{H}]$ ије било ниског начина који Јаковљевић није употребио у току нашег боравка у Л. да нам загорча живот: усред зиме нестајало је дрва, (...). - И никад на колективни злочин не узвратисмо злочином. Нестајало нас је, тописмо се под ударцима огња и мача (...). - Издају живци, нестаје стрпљења, све је мање молитви и све више клетви (...). - Постепено нестаје јутарње свежине, роса испарава (...). (EKCJ) - Жирафе су иначе биле кратког врата, онда је временом нестајало хране које су могле да пасу и брсте. (ЕЛИ)

(76) $[\mathrm{H}] \mathrm{a}$ подлози [трофеја] где се гравирају године светских првенстава и прваци понестаће места (...). - Већ су били с једне и с друге стране просекли камениту и стрму обалу, кад понестаде новца (...) - [У] ресторану је понестало раслађених боца (...). (EKCJ) - [У] мом сепареу је понестало ваздуха и сетим се климе па је још брже заборавим. - Проблем је што је у Резервату „Увац” понестало простора за гнежђење белоглавих супова (...). - Будућност јесте у веганима, кад понестане меса[,] јешћемо њих. - [B]ише није довољан један „Капиталац” попут Мишковића (а некако је и понестало таквих, нарочито оних који нису „у талу” ове или оне врсте) (...). - То што те је бивши дечко преварио (...) не значи да је понестало добрих мушкараца вредних твоје пажње (...). - Прво сам приметио у јубиларном броју да нема ниједне [слике глумице] (...). Није ваљда да је понестало лепих младих глумица? (ЕЛИ) 
(77) Да је сваке године понестајало новца у буџету (...) - Новца је понестајало и за плате и за текуће одржавање. - Последњих десет година понестаје у Словенији добрих прозних писаца. (EKCJ) - Од четири производне линије Нутеле ради само једна (...), наводи Коншел и напомиње да „полако понестаје сировина". - На Фарми понестаје хране. - Како је Први светски рат све више беснео, а муниције и оружја је понестајало, жене су ангажоване у фабрикама (...). - Није било струје, горива, у здравственим установама понестајало је лекова и санитетског материјала. - Убиство певачице из Борче потезало се увек када би понестајало тема или бензина у руским авионима. (ЕЛИ)

Као изузетно стилски маркирани делују примери с уникатним ентитетима одн. генитивним номиналима апсолутне референцијалне одређености и специфичности (уп. (74a)), а номинатив је најлакше заменљив генитивом када је њиме означена конкретна или апстрактна материја (уп. (74в)). Штавише, када се подразумева да та материја не нестаје одједном, већ постепено, као нешто што се „троши”, па се глаголом нестати означава крајњи резултат трошења, тада номинатив скоро да није ни могућ - уп. последњи пример у (74в), где бисмо заменом генитива номинативом добили граматички могућу, али семантички много теже уклопиву зависну реченицу ...cве док није нестао новац, јер би примарна интерпретација била да је неко сав новац одједном узео одн. украо.

Иако глагол нестати ни с особним номинативним субјектом не подразумева његово вољно ангажовање, оно се може актуализовати нпр. употребном прилога намерно (уп. [О]бавезно поменути причу како је Стив Џобс у ствари намерно нестао из јавности и сада повучено живи (...) [ЕЛИ]), док с генитивним субјектом таква могућност не постоји (уп. Стива Џобса је намерно нестало из јавности), а једина интерпретација била би да је за такву ситуацију одговоран неко други (као у [B]одитељ објави да неће да верује да је струје намерно нестало (...) [ЕЛИ])

Ако је посреди „мобилна” егзистенција, тј. егзистенција која није инхерентно повезана с одређеном локацијом, онда се „нестанак” може концептуализовати као „премештање” (на другу, непознату локацију), па се у примерима често наилази на посебну одредбу за место почетка кретања ( $\underline{C}$ трга је нестало људи, Из благајне је нестало новца и сл.), што није могуће ако постоји инхерентна веза егзистенције и локације (Уп. само $У$ стану је нестало струје, али не *Из стана је нестало струје); ни глагол понестати не допушта овакав аблативни адвербијал.

Судећи по дефиницији у $P M C$, глагол понестати има амбивалентну семантику: он значи „подоста, прилично нестати, готово нестати”, али и „престати бити, постојати, потрошити се”7, а из грађе смо могли закључити да обично није ни могуће утврдити о ком се значењу ради, нити је у датом

\footnotetext{
${ }^{7}$ Нејасан је и семантички допринос префикса по-: И. Клајн је склон да га сматра ингресивним префиксом (као у повести, побунити се) (КлАлн 2002: 266), али упућује и на мишљење И. Грицкат, која сматра да је „основни садржај глагола донекле деминуиран: то није 'нестанак' до краја, већ осетно 'смањење', чиљење"” (ГРицкАт 1995: 26).
} 
контексту уопште релевантно да ли је нечега нестало „сасвим” или „подоста". Оно што је битно јесте да се и овде ради о конкретној или апстрактној материји (генитив једнине) или скупу конкретних или апстрактних ентитета (генитив множине) који су подложни постепеном смањењу количине или броја, односно „трошењу”, и чија је егзистенција имплицитно или експлицитно локализована - и по томе је овај глагол мање-више еквивалентан глаголу нестати у једној од раније поменутих употреба (У банкомату је (по)нестало новца), док у другим није, па се супституцијом добија неграматична реченица (yn. * Моје мајке је понестало с прозора).

Што се тиче несвршених парњака, за њих важи исто што и за друге глаголске видске парове: могу означавати понављану ситуацију, као и ситуацију у њеном трајању.

\section{4. „Неегзистенција”}

1.4.1. Да нешто не постоји или да негде нечега нема - исказује се управо главним егзистенцијалним глаголима (имати, бити, постојати) употребљеним у одричном облику ${ }^{8}$, па не изненађује чињеница да глаголи који својим потврдним обликом означавају „неегзистенцију” - имају и другу, важнију, семантичку примесу. У такве глаголе убрајамо мањка(ва)ти, недостајати, оскудевати, помањка(ва)ти, (ус)фалити (као и арх. достајати, ентантиосемично у односу на значење из т. 1.1.7; у овом значењу нисмо нашли потврда за генитивну конструкцију). Наводимо најпре примере:

(78) [Новинарка се] „прославила” текстовима и коментарима „у којима није мањкало говора мржње, па и ратног хушкања. $(E K C J)$ - У Хоџићима стада и успомена никада није мањкало. - Фил је био некако оскудан, мањкало је пилетине (...). - Све су [фотографије] биле благо мутњикаве, мањкало је детаља (...). - Комплетирано је шесто коло Јуниорске лиге Србије, у коме није било изненађења, а мањкало је и неизвесности. - Ратова и битака није мањкавало. (ЕЛИ)

(79) Већ пре недељу дана почело је да недостаје хране и праха. (РСАНУ) - Не само да тамо [= у Швајцарској] недостаје висококвалификованих радника, него и запослених на пољу услуга. - Извештачи су лењи, уредници плашљиви и зато недостаје добрих прича у медијима (...). - Невероватно је колико у Србији недостаје таквог материјала. - Још увек ту недостаје неких камичака које ће истраживачи накнадно уградити у овај мозаик (...). - На синоћној гала забави (...) није недостајало доброг расположења, сјајне атмосфере и атрактивних гошћи. (ЕЛИ)

(80) [A]ко тражиш животињске пориве, тога овде не оскудева. - [A]тмосфера је (...) била на завидном нивоу, док друштва, пића и добре музике није оскудевало. (ЕЛИ)

(81) Учеснице су стизале из целог света[,] тако да је помањкало паркинг места за метле. - Рокенрол је слобода, бунтовност, а тога је помањкало у 21. веку. -У роману не помањкава ни женских ликова јаке персоналности (...). (ЕЛИ)

\footnotetext{
${ }^{8}$ Имати и немати не сматрамо различитим лексемама.
} 
(82) Кад усфали вина, и ракија је добра. $(P M C)$ - Ако би гдегде и усфалило „аутентичне традиције”, важило је гесло - нема проблема, ће измислимо... - Онда [на фарми] почели да фале пилићи. Усфалило и гушчића. (...) Е, ондак је усфалило и гусака и патака и живине. (ЕЛИ)

(83) И овде је фалило свега, од игле до перспективе. - Било је добро, било је топло; мислио сам на плаво небо и широке чисте плаже, али је ипак било тужно - ту је дефинитивно фалило неке људскости. (ЕЛИ)

Оно што глагол какав је недостајати разликује од пуког егзистенцијалног „не бити” јесте модална компонента „потребе” или „очекивања” да (на датом месту) датог ентитета буде, односно да га буде у већем броју, количини или мери. ${ }^{9}$ И то важи за све овде побројане глаголе, уз напомену да у највећем броју случајева где је глагол у одричном облику имамо посла, заправо, са литотом (тога није недостајало $\rightarrow$ тога је било (доста)). Такође, сви ови глаголи употребљавају се и у посесивном значењу (в. т. 2).

1.4.2. Док глаголи из претходне тачке могу значити не само да нечега нема уопште већ и да га нема у довољној мери, количини или довољном броју, глаголи изостати и изостајати означавају само потпуну „неегзистенцију" неког појма, уз, поново, претпоставку да се његова егзистенција „очекује". ${ }^{10}$ Најчешће се користи у личним конструкцијама, па примера с генитивним субјектом немамо много. Међу одричним примерима и овде доминира литота. УП.:

(84) Ни у 2019. људска права се неће поштовати ако изостане дебате. - Морамо да се спремамо за отпор потпуној издаји КиМ чак и ако изостане подршке од Русије. - [Произвођач] се трудио да плоча остане разумно ценовно позиционирана и израђена што квалитетније, па је изостало неких мање потребних детаља који (...). - Материјала и инспирације за сценарија не би изостало. - Засигурно има шта да се научи, али ни забаве не би изостало... - [У] таквим случајевима напетости сигурно не би изостало. - Ни у овом коментару није изостало тих нискости и подлости (...). (ЕЛИ)

\section{2. Преобраћање егзистенције у посесију (и обратно)}

Инхерентна повезаност когнитивних одн. семантичко-граматичких домена егзистенције и посесије у језицима одавно је уочена и добро документована (в. нпр. ЛАлонс 1967, ХАлнЕ 1997 и тамо цитирану литературу). Када се локација на којој нешто постоји концептуализује као део нечије личнЕ СФЕРЕ,

\footnotetext{
${ }^{9}$ Ову „потребу” или „очекивање” вероватно треба сматрати пре делом лексичког значења него пресупозицијом. Пресупозиција би, наиме, требало да буде отпорна на негацију (ЛЕвинсон 1983: 178), а тест негације овде показује да се могу негирати како „неегзистенцијална”, тако и модална компонента: ако се после тврдње да у сефу недостаје новца испостави, након истраге, да $y$ cефу (заправо) не недостаје новца , то може бити отуд што је новац лоше избројан (негирана је неегзистенциајна компонента: „није тачно да га нема”), али и зато што је очекивање било промашено, јер је, рецимо, било исплата које нису ваљано прокњижене (негирана је модална компонента: „није тачно га да треба бити у тој количини”).

${ }^{10}$ На питање да ли ово „очекивање” сада припада прагматичком или лексичкосемантичком плану, нисмо сигурни да можемо дати поуздан одговор.
} 
онда уместо месног адвербијала бива употребљен особни номинал у дативу $^{11}$, а егзистенцијална семантика трансформише се у посесивну, с дативним посесором и (номинативним односно) генитивним посесумом:

(85) $\Downarrow$ Нама је нестало кафе. ( $\approx$ „Нисмо имали / немамо више кафе.”)

Већина глагола из претходних тачака допуштају овакву синтаксичко-семантичку трансформацију, а за неке се, као што је група глагола типа недостајати, посесивне дативне конструкције могу сматрати и примарним, па би егзистенцијалне конструкције (из т. 1.4.1) биле њихови трансформи.

Дативни номинал у свим овим конструкцијама налази се типично у иницијалној, тематској позицији (сем ако није енклитички реализован), и може

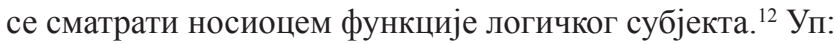

(86) неста(ја)ти, понеста(ја)ти:

Готово јој је било нестало даха. (РСАНУ). - Престао је онда када му је нестало снаге за ту одбрану. - Даница ће отићи само ако јој нестане цигарета (...). (ЕЛИ) - Кад породиљи нестане млека, она у младу недељу изговара следећу басму: (...). - Био је блед и нестајало му је ваздуха. (EKCJ) - Мени полако нестаје инспирације. (ЕЛИ) - Мало ми је као понестало даха. - [E] у тај мах свакоме понестане воље да се бори против Божје казне. - Пошто им је понестало новца, остатак су намириле (...). - Еролу је понестајало снаге. - Морам да прекинем. Понестаје ми папира. $-[К]$ леветницима УКС понестаје аргумената. (EKCJ)

(87) тећи, трајати; оста(ја)ти, преоста(ја)ти:

Борио се док му текло хране и џебане. (PMC) - Ја се тебе не бојим / Док ми деце траје. (Даничић 1958: 91) - (...) расположење градских званичника којима једва да је остало снаге да обележе још један Дан града (...). (...) да буџет скроје тако, да им остане новца бар и за одмор. (EKCJ) - Кад год ми остане хране[,] ја ставим поред контејнера. - Кад му већ не беше остало ничега што би могао дати (...). (ЕЛИ) - Да ли је то привилегија слободног уметника или и запосленој жени остаје времена за домаћинство? - $(E K C J)(\ldots)$ јер не може бити побољшања ако привреди не остаје новца за инвестиције (...) - Прошла зима није тако јака, па ми је остало дрва од претпрошле године. - Они мало старији (...) сматрају да је жени место у кући, а (...) ако јој преостане времена, може да се посвети и каријери. - Уколико вам је преостало неког сира, измрвите га преко бургера пред крај печења. - [О]ни су толико заљубљени у себе, да им практично није преостало љубави и за вас. (ЕЛИ) - [Н]ије ми више преостајало времена да уз превођење уређујем примљене рукописа. $(E K C J)$ - Паљење ове лампице указује да вам преостаје горива још само за 50 км. (ЕЛИ).

\footnotetext{
${ }^{11}$ О ПојмовИМа ЛИЧНЕ СФЕРЕ (енгл. personal sphere) и цИљАНЕ ОСОБЕ (енгЛ. target person), односно дативу као главном граматичком експоненту семантичке улоге циљане особе, в. ДомБРОвскА 1997, ПАлић 2010, као и СтиПчевић 2014.

${ }^{12} \mathrm{~A} \mathrm{ако} \mathrm{генитивни} \mathrm{субјекат} \mathrm{и} \mathrm{даље} \mathrm{сврставамо} \mathrm{у} \mathrm{категорију} \mathrm{логичког} \mathrm{субјекта,} \mathrm{то} \mathrm{би} \mathrm{значило}$ да овакве конструкције садрже два логичка субјекта, што не може бити задовољавајуће решење; в. т. 5 .
} 
(88) доста(ја)ти, дотећи/дотицати, дотрајати; претећи/претицати: Уздао се да ће му достати блага за много година. (РСАНУ) - [M]ора што пре изрећи све (...) јер му касније неће достати даха, снаге, гласа. (EKCJ) - Јер ми не би достало времена кад бих стао приповиједати о Гедеону (...). - Бранку баш није достајало времена ... да га посети. - Није му достајало ријечи, како да се нахвали. - Овде мало коме сељаку не дотече жита преко целе године. (PCAHУ) - [H]е могу да се жалим да ми не дотекне времена за ово или оно (...) - Једва би им дотицало новца за основне потребе. (ЕЛИ - Ако непрестано стане овако трошити ... неће [му] дотрајати новаца. (РСАНУ) - Тако је мајци и оцу претекло пара за куповину летачке опреме (...). (EKCJ) - (...) па нам је амбиција да уколико нам претекне пакетића[,] обрадујемо и дјецу из других градова (...). - Није ни мени претицало новца, али сам решила (...). - [И]пак му је претицало времена да се који сат посвећује својим старим навикама и радостима. (ЕЛИ)

(89) мањка(ва)ти, недостајати, оскудевати, помањка(ва)ти, (ус)фалити $:^{13}$

Док је њега и од њега трага | Да му никад не мањкаје блага (РСАНУ) - Збогом (...) велики црногорски јуначе, да Бог да, докле Црне Горе трајало, никад јој таквих витезова не мањкавало. - То што ми мањка искуства у овој области, сматрам својом предношћу. - Некако ми тешко падају и шетње са бебом (...), као да ми мањка енергије и воље. (ЕЛИ) - Што јој је недостајало животна искуства, то јој се надокнадило природним умом. $($ РСАНУ) - Њему недостаје праве инспирације (...) - Поплавски осети да му недостаје ваздуха. ( $E K C J)$ - Није му оскудевало ни памети ни оштроумља. (ЕЛИ) - Како мислиш брзо ће доћи? Помањкава нам времена. - У овој нашој (...) Црној Гори су (...) 90\% судија суткиње, изгледа да нам помањкава кадрова (...). - Ипак, среће му је овде помањкало, за оно за шта му је била потребна! $(E K C J)$ - Може нам се десити да промашимо прилику (...) само зато што нам је помањкало стрпљења. - Усфалило пара Лали[,] па је одлучио да Соса оде да (...) заради нешто. (ЕЛИ) - Овој земљи никада није фалило лекова (...). ( $E K C J)$ - То им је (...) давало могућност да одржавају предност, а нама је фалило самопоуздања. (ЕЛИ)

\section{3. Конструкиије с другим глаголима}

Као последњу класу глагола који се релативно често користе с генитивним субјектом наводимо оне којима се исказује потреба (затребати, требати, требовати, спотребити се, устребати) или жеља (прохте(ва)ти се, усхтети се, хтети се). ${ }^{14}$

(90) Позвао [је лекара] кад год му је затребало лекарске помоћи. (РСАНУ). - [К]ад му затреба млека за болесну децу, он мора да иде чак у Кросјенку. $(E K C J)$ - Ако ти затреба радника... Ту сам. Тражим посао. - [C]ве у свему, ако ми затреба тог уља, обратићу ти се (...). (ЕЛИ). - Луки се је било

\footnotetext{
${ }^{13}$ Детаљнију анализу ових дативних конструкција дали смо у Стипчевић 2014.

${ }^{14}$ Глагол требати је овде пунозначан и не сматрамо га модалним. - М. Стевановић генитивни номинал уз ове глаголе сматра неправим објектом, премда касније додаје да је овај партитивни генитив „на известан начин субјекатског одн. објекатског карактера” (СтЕВАновић ${ }^{4} 1989:$ \$187). - Дативне конструкције из ове тачке такође смо детаљније анализирали у Стипчевић 2014.
} 


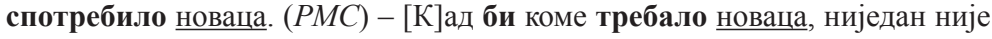
се обраћао њему лично (...). - Мондријану је требало времена. - Њему је требало покрета, замора, промене места, простора... - Мени треба пара, а они ми шаљу машине! $(E K C J)$ - Комшији је намерно цркла крава, баш кад је нама требало млека! - Мајка сам петоро деце и сретна бака шесторо унучади, којима треба чистог ваздуха. - Нима највише треба таквих људи, (...) мединицара (...). - Свакако нам треба писаца који ће циљати на тинејџере и мало старије (...). (ЕЛИ) - Мал' по мал' граду с' примакао, И тек полу града поткопао, Ал' му сада требује барута (...). (EKCJ) - Ама ово је Додику устребало пара да заврши вилу на Дедињу. - А ако (...) не умеднеш сам погодити одмах свој пут, те ти устреба савета (...), отиди Рајнхолду (...). (ЕЛИ)

(91) Тетребовине ти се прохтело. (РMC) - Једне вечери, једна девојчица се расплакала, јер јој се прохтело пекмеза. - Изнебуха њој се прохтело секса и уживања. - Људи су, дакле, сами криви: дат им је био рај, њима се прохтело слободе (...). - [Он] je de facto бивао и премијер, и шеф дипломатије, и министар кад год му се усхтело ресора (...). - [К]о бегунца прима, крив је скупа с њим; не значи ли то де се и теби тућег власништва усхтело. (ЕЛИ) - Њему се хоће лаког живота и власти. (РМС) - Хтело ми се оног мириса бора и мора, који само на Јадрану има. (ЕЛИ)

Ваља напоменути и да уз глаголе за исказивање потребе дативни „носилац потребе” понекад и изостаје:

(92) Драго ми је да вам се свиђа. А требало је стрпљења са феферонама, руке су ми биле два дана „љуте” после тога. - Кад год је устребало течности, подливао сам оном водом од кувања рибе. - Јесте да за ово треба труда и жеље, али ако се прати ситуација увек се може издвојити 10 минута (...).$[\mathrm{J}]$ ош јесенас (...), морало је да се њиве нађубре, што ће рећи требало је пара за куповину ђубрива, после је требало поорати, што ће рећи требало je пара за гориво, (...) све до следеће јесени и жетве за коју опет треба пара... И тако укруг. (ЕЛИ)

Тада би се могло сматрати да је носилац потребе одређен, али подразумеван (као у првом примеру из (92), а можда и у другом примеру, ако се узме да испуштени номинал гласи јелу), или пак неодређен одн. уопштен (последња два примера из (92)).

Чини се да се уз глаголе типа требати генитив претежно употребљава онда када је предмет потребе неодређена количина неспецифичне конкретне или апстрактне материје или неодређени број неспецифичних бројивих ентитета.

То би могло важити и за глаголе типа прохтети се, мада су с њима ствари нешто сложеније: стиче се утисак да „десни” номинал у таквим конструкцијама метонимијски заступа целу ситуацију (Њему се прохтело пекмеза $\leftarrow$ Њему се прохтело да једе пекмез(а)). 


\section{Генитивни субјекат као корелат генитивног правог објекта}

\section{1. Безличне пасивне конструкције}

4.1.1. Као што је познато, у српском језику пасивне конструкције граде се на два начина - уз помоћ трпног глаголског придева (пасивног партиципа) и уз помоћ рефлексивне речце $c е$. Први се отуда обично назива партиципски, а други рефлексивни. У поређењу с одговарајућом активном конструкцијом, ефекат пасива типично се огледа у демоцији агенса, који најчешће бива испуштен, и промоцији пацијенса, који сада заузима место субјекта. ${ }^{15}$ Типична пасивна реченица јесте лична, субјекатско-предикатска.

Такође је добро познато да се прави објекат понекад може реализовати не акузативом, већ партитивним генитивом (укључујући и „словенски”). Међутим, ако реченицу с генитивним правим објектом подвргнемо деагентизацији, уочићемо да резултат, заправо, може бити двојак:

(93) У млеко је неко сипао воде.

а. У млеко је сипана вода.

б. У млеко је сипано воде.

Под (а) је дата каноничка партиципска пасивна конструкција, са номинативним граматичким субјектом и конгруентним предикатом. У конструкцији под (б) десни номинал је остао у истом облику, а предикат је, пошто не може конгруирати с генитивом, преузео неутрални, безлични облик.

На ову врсту конструкција скреће пажњу С. Танасић (2018), али их не сматра пасивним: генитив у њима сматра и даље објектом, сврставајући их у ред безличних партиципских реченица попут На юих је пуцзано (истина, као нарочит случај, будући да се оне иначе формирају од непрелазних глагола).

Чини се очигледним да су овакве конструкције могуће с оним глаголима и у оним контекстима где је у активу допуштен генитивни прави објекат, с тим што морају постојати комуникативно-прагматички разлози да се реченица деагентизује (у те разлоге овом приликом не можемо улазити). Стога примере није тако лако наћи: ${ }^{16}$

(94) Зар толико не видите да му [= аутомобилу] је позади додато неких сувишних материјала и светла су прелепљена (...). - Све што сам пробао (...) било је некако прејаког укуса. Не умем да објасним боље, али као да је додато неких појачивача (...). - Рађено ми је квачило[,] па је досипано уља јер су вађене полуосовине. - Да би се корисници радно ангажовали[,] набављено је материјала за израду предмета који се продају (...). - Посланица каже да не зна ни да ли ће бити ускоро нађено решења за раднике који раде на изградњи Коридора (...). - Па је ли нађено оружја и муниције за извршење издајничког предузећа? - [П]ретрагом куће му је нађено дроге и оружја у полицијској акцији (...). - Декларисани терет требало је да буде „санитет-

\footnotetext{
${ }^{15}$ Сажет приказ различитих погледа на пасив(изацију) кроз примере из разних словенских језика може се наћи у раду СЈЕвЈЕРскА 1988.

${ }^{16}$ Изоставили смо случајеве као што је вођено је рачуна... јер се ради о устаљеном обрту који цео, заправо, функционише као предикат, а у активу не допушта акузатив (уп. *вођен је рачун...).
} 
ски материјал”, али је на броду нађено разних противтенковских ракета - (...) обзиром да је вода исувише тврда, а није стављено соли у уређај [= машину за судове]. - У млеко се умочи игла којом се плете и лагано се извуче из млека; ако на игли остане млека, није сипано воде, а ако не остане[,] сипано је воде у млеко. - [А]ли се не слажем да је „програм” био у проблемима, него држава и да зато није давано пара за програм. -Пуно је гушће и самим тим је видљиво да није додавано воде као код брендираних уља. - У питању је храстов паркет (...), коришћен је лепак (...), није додавано воде у њега и паркетар га није штедео. - Претресом села Узарићи није нађено никаквог напуштеног оружја (...). - У подацима који су коришћени у овој анализи није нађено таквих неправилних мерења и екстремних вредности (...). - Родитељима моје комшинице[,] који су помрли прошле године[,] ни динара није дато да санирају кућу (...). - Нишовић (...) тврди да Мађарима неће бити плаћено ни цента од тражених 150.000 евра (...). - Радницима (...) још није исплаћено ни динара. - Јер, у име сваког занесењаштва је проливено море крви, а у име доброг војника Швејка није проливено ни капи. (ЕЛИ)

Поредећи прави објекат у акузативу и прави објекат у генитиву (у потврдним реченицама), Д. Гортан-Премк запажа да се „поред партитивности оваквим синтагмама с генитивом обележава и неодређеност објекта", и то „не само неодређеност по количини већ и неодређеност уопште” (ГорТАН-ПремК 1971: 88). Исто то, рекли бисмо, важи и за генитивни субјекат у горњим (потврдним) примерима. Што се тиче одричних примера, тамо генитив свакако одговара „словенском” генитиву правог објекта, у којем се може наћи и бројив појам у једнини, нарочито у устаљеним изразима под појачаном негацијом (ни цеента, ни динара, ни капи и сл.).

4.1.2. На исту појаву наилазимо и код рефлексивног пасива:

(95) У смесу најпре додамо воде...

а. У смесу се најпре дода вода...

б. У млеко се најпре дода воде...

И опет, као и у претходној тачки, деагентизација полазне реченице с партитивним правим објектом има два могућа исхода: каноничку пасивну субјекатско-предикатску реченицу (а) и безличну реченицу с генитивним субјектом (б). Како смо поменули у Уводу, на овакве реченице указује још Ђ. Даничић, а С. Танасић их помиње као пример за обезличне реченице од прелазних глагола где се објекат ипак исказује (ТАнАсић 2004). Морамо се, ипак, подсетити да се увођењем рефлексивне речце се може обезличити (одн. деагентизовати) реченица с практично било којим личним ${ }^{17}$ глаголом који има особног агенса: ако је у полазној реченици глагол (употребљен као) непрелазан, добићемо обезличену, бесубјекатску реченицу (Тада су људи дуже спавали $\rightarrow$ Тада се дуже спавало; Људи су ужурбано радили $\rightarrow$ Ужурбано се радило; Људи су веровали свакоме $\rightarrow$ Веровало се свакоме и сл.); ако је пак у полазној реченици глагол (употребљен као) прелазан, исход мора бити пасивна субјекатско-предикатска реченица (људи су ужурбано градили кућу

${ }^{17}$ Термин лични глАгол овде користимо онако како је изложено у раду Стипчевић 2018. 
$\rightarrow$ Кућа се ужурбано градила; Људи су паковали ствари у кофере $\rightarrow$ Стваpu су се паковале у кофере). Другим речима, ако посматрамо шта се у овом процесу догађа с глаголским допунама, у српском језику све друге глаголске допуне кроз деагентизацију пролазе „нетакнуте” - осим правог објекта! Пошто се обезличене реченице с акузативним правим објектом (Градило се кyћy) у савременом језику углавном не користе и сматрају се нормативно неприхватљивим ${ }^{18}$, необично би било да сасвим другачије правило важи за генитивни прави објекат. Стога нам се конзистентнијом чини анализа по којој се конструкција каква је (95б) сматра (неканоничком) инстанцом пасива, а генитивни номинал у њој - генитивним субјектом. ${ }^{19}$

О вредности генитива и могућностима за образовање оваквих конструкција важило би све што је важило и за партиципске конструкције из претходне тачке, а с обзиром на то да је рефлексивни пасив у српском језику чешћи од партиципског, примери нису ретки:

(96) Гледало се серија и филмова, било је лепих глумица и усклађених парова, али ово двоје су неко ко се ретко среће. ${ }^{20}$ - За шиш ћевап се дода бибера и љутих феферона (..). - Ја сам открила чај од ароније (...), још кад се дода димуна, преукусан је... - Залити га млевеним парадајзом у који се дода соли по укусу и конзерванс. - Онда се додају грашак и шаргарепа (...), па се налије воде да буде чорбасто. - (...) исецкани лук ставити да се динста једно сат времена. У то да се долива воде чим мало воде испари. - [Р]азменио је неколико реченица са њим (...) и наредио да му се донесе свеже воде. - Требало би да се доспе уља ако га нема онолико да грејач плива у њему (...). - Имало се пара, примала се тринаеста плата. -Па и кад се једе сланине и лука (...)[,] ако је то домаће или без хемије[,] онда та храна није ризична. - А што се пуца ноћас (...)?! Или се јело пасуља или неко провјерава старе цијеви (...). - Мој савјет ти је да прво пробаш неку дијету, да се једе меса, aја, рибе и салате[,] па да видиш како се топе масти. - Да је базен скупа инвестиција, да се крало пара за изградњу и да је скупо одржавање, јесте, али (...). - Сутра једноставно мора да се нађе снаге и мотива да се одигра на високом нивоу. - Готово никаква археолошка истраживања нису спроведена у Санџаку[,] а тамо гдје се копало налазило се таквих ствари да је то готово епохално. - [А] кад би дошли у клуб 'Обала', палио се агрегат, налазило се неког пића, ми смо свирали и све је изгледало као у сну. - Уз сву енергију још се има снаге и за кореографију. - [А]али има места и за огледала и за слике ако се има укуса. - [К]ада се крене из хотела Титоград (...) лево има једна велика чесма (...) и ту може да се наточи воде. - Кад пијемо кафу[,] он [= дете] добије у шољицу млеко, тако се осећа као део друштва, а кад се пије ракије[,] и он добије у исту чашу воду. - Metistos на грчком значи „неопијајуће”, али, богами, кад се

\footnotetext{
${ }^{18}$ УП. МилошЕвић 1980, Суьотић 1996 итд.

${ }^{19}$ То не значи да анализу из ТАнАсић 2004 одбацујемо као погрешну. Разлике у тумачењу језичких факата по правилу проистичу из различитих, често имплицитних, теоријских полазишта, различитих терминолошко-појмовних система и, уопште, различите концепције синтаксичке анализе.

${ }^{20}$ Овај пример је занимљив и зато што илуструје једну врсту стилски маркиране, „форсиране" деагентизације, релативно честе у разговорном језику - у њему агенс, наиме, није ни уопштени ни колективни, већ је агенс - саิм говорник („Гледала сам серија и филмова...”).
} 
попије тог вина... - Кад се маст угреје, стави се ситног исеченог белог лука, мало алеве паприке (...). - У средину између две коре се стави сира (...). - [П]отребно је да постоји снажна мотивација (...), као и да се стекне искуства и поради на себи. - [Н]ема се ни динара за бацање. - Кад се нема аргумената[,] онда се напада ad hominem. - И кад је најтеже и кад се нема ничега $[$,$] добра и јака породица то изгура. - [К]олико катастрофа$ доказаних има (...) за које се не нађе никаквог оправдања (...). - Касно сам се одлучио за пут и у Брну се није могло наћи слободног места. (ЕЛИ)

\section{2. Модалне „криптопасивне” конструкције}

4.2.1. Остаје да се осврнемо на два типа модалних рефлексивних конструкција које испољавају „криптопасивну”21 природу, а могу садржати генитивни субјекат као алтернативу номинативном. Њихову синтаксу, семантику и продуктивност подробно смо представили другде (Стипчевић 2015), па ћемо овом приликом само укратко навести њихове карактеристике и додатно их илустровати.

Оба типа употребљавају се - пре свега у разговорном језику - за исказивање потребе или жеље за (не)вршењем радње именоване глаголом. Први се гради искључиво од несвршених особно-личних глагола најразличитије семантике и обавезно садржи речцу се и дативни логички субјекат, који означава доживљавача и којим је замењен номинативни агенс. Ако је глагол (употребљен као) непрелазан, конструкција ће бити безлична (Спавао сам $\rightarrow$ Спавало ми се) $)^{22}$. Ако је глагол (употребљен као) прелазан, пацијенс може бити укључен на два начина: или као граматички субјекат у номинативу (Пио сам воду $\rightarrow$ Пила ми се вода), у ком случају је конструкција лична, субјекатско-предикатска, или пак као генитивни субјекат (Пио сам воде $\rightarrow$ Пило ми се $\underline{\underline{B o d e}})$, у ком случају је конструкција опет безлична. Како видимо, одстрањивањем агенса, односно његовим преосмишљавањем у дативног доживљавача, и промоцијом пацијенса на субјекатску позицију - остварује се ефекат који је одлика и регуларне пасивне трансформације. У таквој дативној модалној конструкцији генитивни субјекат моћи ће се употребити (уместо номинативног) под приближно оним условима под којим би се употребио у регуларној рефлексивнопасивној реченици из претходне тачке (Пило се воде); но, пошто радња мора бити таква да говорник може осетити потребу или жељу да је врши (или пак не врши), а глагол при томе мора бити несвршен, располажемо са мало примера:

(97) Јело ми се цварака и ука. - Па кад ми се једе пите, ја једем питу. - Много ми се пило воде. - Не даје ми се пара за метални гриндер (...), треба ми нешто до 1000. - [Н]ије ми се давало пара за неку скупљу крему са фактором. - [H] а крају [сам] прекинуо [филм] нешто после половине; не губи ми се времена (...). - Објасни, ако ти се троши времена на мене. (ЕЛИ)

\footnotetext{
${ }^{21}$ Термин је преузет из Поповић 1998.

${ }^{22}$ Реченица лево од стрелице представља немодалну варијанту, која би се употребила да се дата радња заиста вршила, тј. да је била у домену реалног.
} 
4.2.2. Конструкције из претходне тачке означавају трајне ситуације и граде се само од несвршених глагола. Ако се пак жели исказати пунктуална ситуација, тј. западање у стање жеље или потребе за вршењем неке радње, говорник има на располагању творбени комплекс $n p u-+c e$, којим се од мотивног несвршеног глагола добија свршени повратни глагол (нпр. присnаваmu ce). Такав глагол обавезно захтева логички субјекат у дативу. Ако је мотивни глагол непрелазан (нпр. спавати), префиксирани глагол биће безличан (приспавало ми се); ако је мотивни глагол прелазан (нпр. јести), префиксирани глагол биће личан, при чему ће субјектом бити означен пацијенс мотивног глагола. Тај субјекат обично је у номинативу (пријела ми се чоколада), али постоји могућност да буде и у генитиву (пријело ми се чоколаде), када се и глагол користи као безличан. И овде, дакле, постоји ефекат какав налазимо у пасивној трансформацији - прави објекат постаје субјектом, а агенс се одстрањује (и преосмишљава као доживљавач) - с тим што се процес одвија на творбеном нивоу. У разговорном језику овакви глаголи често се творе $\mathrm{ad}$ hoc, као нека врста псеудолексема. ${ }^{23}$ Наводимо примере из грађе у којима затичемо генитивни субјекат:

(98) Волео би да ми се тада приједе колача. - [A]ко му се хитно припије ракије[,] онда иде роба и испод набавне цјене (...). - Девојке спавају[,] а мени се баш сада припило воде. - [С]ада [бих] морао да радим (...), али како то често бива[,] баш ми се сада и причитало блогова и прикоментарисало (...). - [И]скусни возач нам [je] кроз зубе промрсио да се стрпимо (...), да би - када нам се свима нагло припишало, пријело и прикуповало сувенира - просто морао да стане на најлепшој пумпи на свету.

\section{Закључна разматрања}

5. У раду су представљене конструкције са преко шездесет глагола, углавном егзистенцијалног и посесивног типа, који својом семантиком систематски фаворизују или, чешће, допуштају употребу генитивног субјекта, као и неколико типова (квази)пасивних конструкција где се генитивни субјекат легитимише као корелат генитивног правог објекта. У Уводу смо поменули да већина граматичких приручника који помињу логички субјекат као могући реченични члан - у ову категорију уврштава и генитивни субјекат. Ниједан приручник не даје прецизну дефиницију логичког субјекта, па ни упутства за његову идентификацију, али даје довољно примера да се може закључити да се има у виду реченични члан који не задовољава формалну дефиницију граматичког субјекта - да је то (непредикативни) номинал у номинативу с којим конгруира предикат - али задовољава комуникативно-прагматичке и семантичке субјекатске критеријуме: да је типично у иницијалној позицији, да на информативном плану типично има тематску функцију, те да се схвата као „носилац ситуације” (ма шта се под тиме тачно имало у виду); а како је та ситуација већином неко психичко и физиолошко стање чији је

\footnotetext{
ства.

${ }^{23}$ Другим речима, говорници се творбеним средствима служе као да су синтаксичка сред-
} 
носилац особа, таквом субјекту, као и типичном граматичком, требало би да буде својствен висок степен референцијалне одређености и специфичности, пресупонирана егзистенција његовог референта независно од ситуације која се исказује и сл. ${ }^{24}$ То важи за случајеве логичког субјекта у дативу (Пери је позлило, Пери се (при)спавало, Пери је хладно), акузативу (Перу је страх, Перу је срамота, Перу боли зуб), па и у другим предлошко-падежним конструкцијама (У Пери је кључало, Из Пере провали јецање и сл.) ${ }^{25}$. При томе се обично узима да се логички субјекат може у реченици наћи заједно са граматичким, номинативним субјектом (који у том случају задовољава само формалне граматичке критеријуме, а не и остале - као у Пери се свиђа Ана, Перу боли зуб). ${ }^{26}$

Ипак, генитивни субјекат из конструкција чији смо преглед дали у претходним тачкама - понаша се сасвим другачије. Прво, типично је не у иницијалној, већ поствербалној позицији, па следствено томе има типично рематску, а не тематску информативну функцију. Друго, постоји јасна тенденција да се користи управо онда када треба у ситуацију укључити квантификативно и/или референцијално неодређен одн. неспецифичан ентитет, или га као таквог представити. Треће, његови типични референти нису особе, већ, бар у потврдним реченицама, конкретна или апстрактна материја одн. множина конкретних или апстрактних бројивих ентитета. А ако референти јесу особе, тада је практично елиминисана свака примеса агентивности (уп. *На тргу се намерно скупило студената). Истина, све ове одлике једнако га, заправо, удаљавају колико од (других типова) логичког субјекта, толико и од граматичког. Својство које, међутим, и даље сматрамо одлучујућим јесте то што се не може никада наћи у истој реченици заједно са номинативним субјектом, будући да заузима управо оно место које глагол за субјекат отвара. Та два, дакле, момента - несличност с другим инстанцама логичког субјекта и способност да у реченици замени номинативни субјекат - јесу, мислимо, довољан разлог да се генитивни субјекат измести из категорије логичког субјекта, те да се сматра неком врстом, у референцијалном и агентивном погледу, „слабе” варијанте граматичког субјекта, која се као могућа јавља само уз непрелазне глаголе, као и у (крипто)пасивним конструкцијама с прелазним глаголима. ${ }^{27}$

\footnotetext{
${ }^{24}$ Ради се о моментима који се обично наводе као типични за субјекат, односно који се често користе за идентификацију ове категорије у различитим језицима (уп. КинАн 1976).

${ }^{25}$ Таквим и сродним предлошко-падежним конструкцијама илуструје се логички субјекат у Поповић 2002.

${ }^{26}$ Тако се поступа нпр. у Поповић ${ }^{13} 2011$, а тако поступамо и у овом раду; у супротном, били бисмо принуђени да, примера ради, сматрамо да дативни номинал у Пери се спава јесте логички субјекат, а у Пери се пије ракија - није. О овом питању има и супротних ставова (в. КовАчввић 2016).

${ }^{27}$ Посебност генитивног субјекта није прошла сасвим непримећено у литератури. К. Фелешко (1995: 69) из сличних разлога предлаже термин кВАЗисуБЈЕКАТ, а став близак оном који овде заступамо наговештен је, али не и елабориран, у радовима Поповић 1998, 2002. - Напомињемо да овиме не искључујемо могућност да се „прави” логички субјекат понекад нађе и у беспредлошком генитиву. Пример за такав логички субјекат у генитиву, по својствима сличан дативном и акузативном, могао би бити Пере се не тичу туђи проблеми, Пере се то дојмило и сл.
} 
Иако је, у начелу, генитивни субјекат заменљив номинативним, тај супститутивни потенцијал - у оба смера - није без семантичко-прагматичких ограничења и запрека, нарочито у конструкцијама с глаголима имати и бити, где је употреба генитива јаче граматикализована него другде. Све те законитости тек треба пажљиво испитати и расветлити, при чему нарочито имамо у виду улогу и утицај негације, у вези с којом смо могли учинити само узгредне напомене и која завређује посебно истраживање (у којем би се, рецимо, објаснила неспорна а неочекивана граматичност примера какав је $\mathrm{Ha}$ наше писмо није стизало никаквог одговора и сл.)

Засад има основа за закључак да постојање генитивног субјекта у српском језику јесте граматичка чињеница. Она заслужује како даља истраживања, тако и примерен граматографски и теоријски третман.

\section{ИЗВОРИ}

PMC: Речник српскохрватскога книжевног језика, I-VI, Нови Сад (- Загреб): Матица српска (- Матица хрватска), 1967-1976.

РСАНУ: Речник српскохрватског књижевног и народног језика, I-XX, Београд: САНУ, 1959-2017.

ЕКСЈ: Електронски Корпус савременог српског језика (верзија СрпКор2013), Група за језичке технологије Универзитета у Београду, www.korpus.matf.bg.ac.rs.

ЕЛИ: Електронски извори српског језичког материјала доступни преко претраживача Google (www.google.rs).

\section{ЛИТЕРАТУРА}

Барић et al. ${ }^{2}$ 1997: Eugenija Barić, Mijo Lončarić, Dragica Malić, Slavko Pavešić, Mirko Peti, Vesna Zečević, Marija Znika, Hrvatska gramatika, II. promijenjeno izdanje, Zagreb: Školska knjiga.

Брабец et al. ${ }^{2}$ 1954: Ivan Brabec, Mate Hraste, Sreten Živković, Gramatika hrvatskoga ili srpskog jezika (II prerađeno i nadopunjeno izdanje), Zagreb: Školska knjiga.

Гортан-Премк 1971: Даринка Гортан-Премк, Акузативне синтагме без предлога у српскохрватском језику, Београд: Институт за српскохрватски језик.

Грицкат 1961: Irena Grickat, „Razvoj značenja glagola imati”, Radovi Naučnog društva SRBiH, XVIII (Odjeljenje istorijsko-filoloških nauka, knj. 6), $67-81$.

Грицкат 1995: Ирена Грицкат, „О неким особеностима деминуције”, Јужнословенски филолог, LI, 1-30. 
Даничић 1858: Ђуро Даничић, Србска синтакса (Део првиј), Београд: Државна штампарија.

Домбровска 1997: Ewa Dąbrowska, Cognitive Semantics and the Polish Dative, Berlin: Mouton de Gruyter.

Ивић 1981: Милка Ивић, „Српскохрватски глаголски облици за исказивање појава које постоје у садашњости", Јужнословенски филолог, XXXVII, $12-24$.

Ивић 1982: Milka Ivić, „O slovenskim egzistencijalno-lokacionim rečenicama”, Studia gramatyczne, V, 7-10.

Јовановић 2018: Александра Јовановић, „Семантичке и синтаксички статус семикопулативног глагола остати", Књижевност и језик, LXV/1-2, 91-105.

Кинан 1976: Edward L. Keenan, "Towards a universal definition of 'subject", [y књизи] Charles N. Li (Ed.), Subject and Topic, New York: Academic Press, 303-334.

Клајн 2002: Иван Клајн, Творба речи у савременом српском језику. Први део: слагање и префиксаиија, Београд - Нови Сад: Институт за српски језик САНУ - Завод за уџбенике и наставна средства - Матица српска.

Ковачевић 2005: Милош Ковачевић, „Пунозначна и копулативна употреба глагола бити", Српски језик, X/1-2, 211-233.

Ковачевић 2016: Милош Ковачевић, „Конкурентност једног типа предлошког генитивног, акузативног, инструменталног и локативног логичког субјекта" [у књизи] Јасмина Дражић, Исидора Бјелаковић, Дејан Средојевић (ур.), Теме језикословне у србистици кроз дијахронију и синхронију: зборник у част Љиљани Суботић, Нови Сад: Филозофски факултет, 305-326.

Кордић 2002: Snježana Kordić, Riječi na granici punoznačnosti, Zagreb: Hrvatska sveučilišna naklada.

Корин 1997: Andrew Corin, „О синтакси егзистенцијалног habere (има) у српском језику, Научни састанак слависта у Вукове дане, 26/2, 45-60.

Лазић-Коњик 2005: Ивана Лазић-Коњик, „О функционално-семантичкој категорији егзистенције у српском језику", Јужнословенски филолог, LXV, 359-374.

Лајонс 1967: John Lyons, “A note on possessive, existential and locative sentences", Foundations of Language, 3/4, 390-396.

Лалевић 1962: Миодраг С. Лалевић, Синтакса српскохрватскога књижевног језика, Београд: Завод за издавање уџбеника Народне Републике Србије.

Левинсон 1983: Stephen C. Levinson, Pragmatics, Cambridge: Cambridge University Press.

Милошевић 1980: Ksenija Milošević, „Jedan negramatični rečenični model u srpskohrvatskom jeziku”, Јужнословенски филолог, XXXVI, 47-64.

Миновић 1987: Milivoje Minović, Sintaksa srpskohrvatskog - hrvatskosrpskog književnog jezika za više škole. Rečenica, padeži, glagoli, Sarajevo: Svjetlost - Zavod za udžbenike i nastavna sredstva. 
Михаиловић 1972: Ljiljana Mihailović, "Existential sentences in English and Serbo-Croatian", The Yugoslav Serbo-Croatian-English Contrastive Project: Reports, V, 67-107.

Палић 2010: Ismail Palić, Dativ u bosanskome jeziku, Sarajevo: Bookline.

Пипер et al. 2005: Предраг Пипер, Ивана Антонић, Владислава Ружић, Срето Танасић, Људмила Поповић, Бранко Тошовић, Синтакса савременога српског језика (проста реченииа), Београд - Нови Сад: Институт за српски језик САНУ - Матица српска.

Поповић 132011: Љубомир Поповић, „Синтакса”, [у књизи] СтАнолчић/Поповић ${ }^{13} 2011,206-386$.

Поповић 1998: Љубомир Поповић, „Деагентив - дистрибуција и употребне вредности активних, пасивних и (псеудо)рефлексивних форми личних глагола са особним агенсом”, реферат на 28. међународном научном састанку слависта у Вукове дане, Београд - Нови Сад, 15-20. 9. 1998.

Поповић 2002: Ljubomir Popović, „Informativna struktura rečeničnih modela”, Кьижевност и језик, XLIX/3-4, 213-240.

Сјевјерска 1988: Anna Siewierska, "The passive in Slavic", [у књизи] Masayoshi Shibatani (Ed.), Passive and Voice, Amsterdam: John Benjamins, 243-289.

Станојчић/Поповић ${ }^{132011}$ : Живојин Станојчић, Љубомир Поповић, Граматика српског језика за гимназије и средюе школе, Београд: Завод за уџбенике.

Стевановић ${ }^{\mathbf{4}}$ 1989: Михаило Стевановић, Савремени српскохрватски језик (граматички системи и књижевнојезичка норма) II. Синтакса (четврто издање), Београд: Научна књига.

Стипчевић 2014: Балша Стипчевић, Дативне рекцијске конструкиије с непрелазним глаголима у савременом српском језику, рукопис одбрањене докторске дисертације, Београд: Филолошки факултет.

Стипчевић 2015: Балша Стипчевић, „Два типа модалних дативних конструкција с речцом се", Српски језик, XX, 173-194.

Стипчевић 2018: Балша Стипчевић, „Шта су то безлични глаголи?”, Научни састанак слависта у Вукове дане, 47/3, 2018, 119-130.

Суботић 1996: Љиљана Суботић, „Још једном о моделу имперсоналне реченице с акузативом директног објекта", Српски језик, I/1-2, 70-77.

Танасић 2004: Срето Танасић, „Безличне реченице са уопштеним агенсом”, Јужнословенски филолог, LX, 41-55.

Танасић 2018: Срето Танасић, „Безличне партиципске реченице у српском језику”, [у књизи] Рајна Драгићевић, Вељко Брборић (ур.), Српска славистика: колективна монографија [Радови српске делегащије на XVI међународном конгресу слависта]. Том I. Језик, Београд: Савез славистичких друштава Србије, 407-423.

Фелешко 1995: Казимјеж Фелешко, Значења и синтакса српскохрватског генитива, Нови Сад - Београд: Матица српска - Вукова задужбина Орфелин.

Хајне 1997: Bernd Heine, Possession: Cognitive Sources, Forces, and Grammaticalization, Cambridge: Cambridge University Press. 
Шпис 1987: Марија Шпис, „О српскохрватским глаголима са егзистенцијалним значењем”, Прилози проучаваюу језика, 23, 95-104.

Balša N. Stipčević

GENITIVE SUBJECT CONSTRUCTIONS: A PRELIMINARY SURVEY

Summary

The author provides a survey of genitive subject constructions in the Serbian language: both of those in which the genitive subject is favoured by certain syntactic and semantic classes of verbs (ima vode, nastalo je problema, nestalo je struje, nedostaje (mi) hrane, treba mi vazduha etc.), as well as of those in which the genitive subject can be regarded as a correlate of the genitive direct object (sipano je vode, jelo se pasulja, jede mi se slanine, prijelo mi se mesa). 